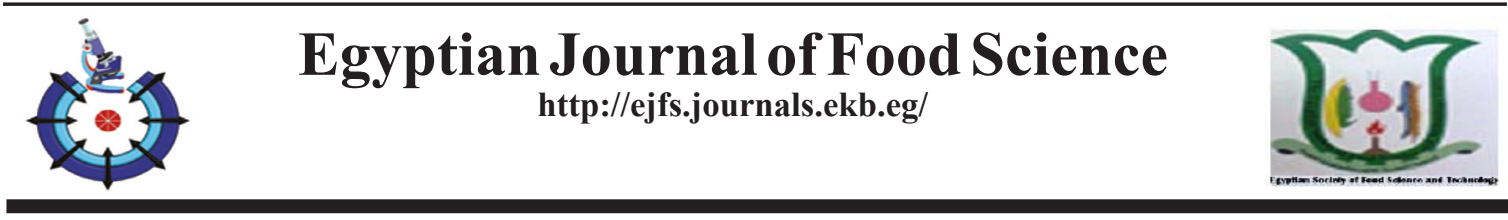

\title{
Nutritional Value of Germinated Quinoa Seeds and Their Protective Effects on Rats' Health Injected by Nicotine
}

Ola Ibrahim El-Desoky Ali

Nutrition and Food Science Department, Faculty of Home Economics, Al-Azhar

University, Tanta, Egypt

\begin{abstract}
$\mathbf{N}$ ICOTINE resulted from heavy smoking raises the risk of developing of chronic liver diseases, hence hepatocellular carcinoma. Nicotine also encourages the proinflammatory cytokins production which would be involved in the injury of liver cell. This study was conducted to investigate nutritional components and protective effect of germinated quinoa seeds on rats' health that injected by nicotine. Thirty male albino adult rats $(150 \pm 10 \mathrm{~g}$.) were used. The rats divided into two main groups; one used as a negative control group fed on basal diet, while other groups used as a positive control group fed on basal diet also and three other rats subgroups fed on supplemented diet with germinated quinoa seeds at three concentrations (i.e. $5 \%, 10 \%$ and $15 \%$ ) for 4 weeks, then injected with nicotine subcutaneously for 15 days. Biological evaluation, lipid profile, liver enzymes, kidney functions, and antioxidant markers were estimated at the end of the experiment. The chemical composition of germinated quinoa seeds demonstrated that quinoa can be considered as a good source for dietary fiber, polyphenols and other antioxidant compounds which raised the nutritional value. The results indicated that kidney and liver functions were restored significantly in rats' groups received quinoa seeds $10 \%$, followed by quinoa seeds $5 \%$ as compared to the positive control group. The nicotine rats group showed significant decrease in triglyceride, VLDL-C, and LDL-C; on the other hand, all supplemented groups with quinoa seeds $10 \%$, followed by quinoa seeds $5 \%$ showed a gradually significant increase in HDL-C. Serum total cholesterol and LDL-C were significantly increased in the positive control group, while they gradually significant decreased in all supplemented diet groups demonstrated. Therefore, this study reveals the health benefits of quinoa seeds in functional foods for heart disease, hypercholesterolemic and patients with liver disease.
\end{abstract}

Keywords: Quinoa seeds, Nicotine, Liver enzymes, Cholesterol, Lipoproteins, Kidney

\section{Introduction}

Quinoa seeds are an excellent pattern of 'functional food' aims at declining the risk of a lot of diseases. Its functional features are provided by vitamins, minerals, antioxidants and fatty acids that mainly contribute to human nutrition, specifically to protect cell membranes, with confirmed good results in neuronal functions of the brain. In addition, its minerals act as cofactors in antioxidant enzymes, which improve the value of its plentiful proteins. These seeds also contain phytohormones, providing another advantage than other plant foods for human nutrition (Antonio et al.,
2010). Quinoa is a good mineral source, it contains higher calcium, $(\mathrm{Ca})$, magnesium $(\mathrm{Mg})$ iron $(\mathrm{Fe})$, and zinc $(\mathrm{Zn})$ than other common cereals, and its content of $\mathrm{Fe}$ is particularly high. It contains also higher $\alpha$-tocopherol and riboflavin (B2) than rice, wheat, or barley. Moreover, its seeds can be a good source of vitamin E. Quinoa can be eaten in many ways such as a rice replacement, a hot breakfast cereal, boiled in water for making infant cereal food. As well, the seeds can be popped like popcorn, ground to use as flour, or sprouted. The sprouts need to be greener before adding to salads (Jancurova et al., 2009). 
Nicotine is a natural alkaloid found in the nightshade plants' family (Solanaceae), mainly in tobacco plants (Nicotiana tabacum) (Wu et al., 2002). The nicotine resulted from heavy smoking raises the risk of developing chronic liver diseases then hepatocellular carcinoma (HCC). As well, nicotine boosts the production of proinflammatory cytokines that would be involved in the liver cell injury (El-Zayadi, 2006). Also, oxidative stress is induced by nicotine, resulting in depleting antioxidant defense mechanisms; reducing glutathione peroxidase in both lung, circulation, kidney, and liver of nicotine-treated animals (Yildiz, 2004 and Muthukumaran et al., 2008). Moreover, maternal nicotine exposure provoked oxidative stress causing liver and kidney histopathological changes in lactating offspring (Ozukutat et al., 2005 and El-Sokkary et al., 2007). As well, Ozukutat et al. (2005) stated that nicotine promotes the oxidative stress in both of Vivo and Vitro. Previous studies revealed that the ability of nicotine to bind to DNA, which causes significantly higher effects of genotoxic in protein-restricted conditions (Bandyopadhyaya et al., 2008 and Banerjee et al., 2010). Nicotine also increases the release of free fatty acids from the liver, as well as the hepatic creation of very-lowdensity lipoproteins (El-Sokkary et al., 2007).

\section{Material and Methods}

\section{Materials}

Quinoa (Chenopodium quinoa Willd.) has been obtained from the private company of agriculture seeds, Herbs, and Medicinal Plants, Cairo, Egypt. Casein, minerals, vitamins, and cellulose were obtained from EL-Gomhoryia (chemicals company), Tanta, Egypt. Thirty male albino rats (Sprague Dawely) Strain) were purchased from the Vaccine and Immunity Organization, Helwan Farm, Cairo, Egypt.

\section{Methods}

Soaking

Quinoa seeds were first cleaned and eliminated from dust, broken particles, and other foreign materials and then soaked for $12 \mathrm{hr}$ in tap water at room temperature, with a ratio of 1:5 (seeds: water $(\mathrm{w} / \mathrm{v}))$. Then non-imbibed water was disposed. The soaking for removing anti-nutritional elements including saponins in the grains, has been reported, (Chauhan et al., 1992; Ruales and Nair, 1993b). Saponins in the external seed layers result in the main shortcoming of quinoa (i.e. the bitter taste of its grains), which have been broadly described as an anti-nutrient because of its strong binding affinity to minerals (Brady et al., 2007).

\section{Germination}

The previously soaked seeds were individually spread on wet jute bags, covered by muslin cloth and one more wet jute bag. Then, the seeds were sprinkled by water every $12 \mathrm{hr}$. till finishing the germination period $(72 \mathrm{hr}$.). The germinated seeds were picked gently with the sprouts, washed, carefully drained, dried in the oven at $50^{\circ} \mathrm{C}$ for $24 \mathrm{hr}$., crushed and stored in labeled polyethylene bags until analysis (Mansour and El-Adawy, 1994)

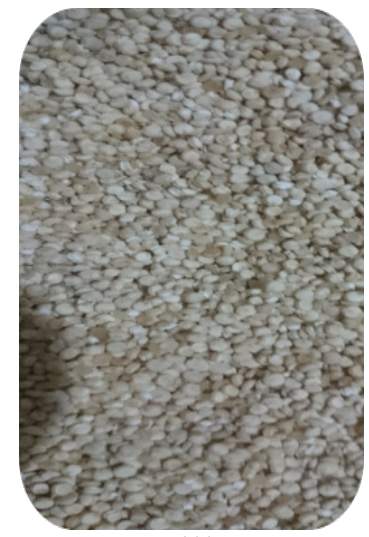

(A)

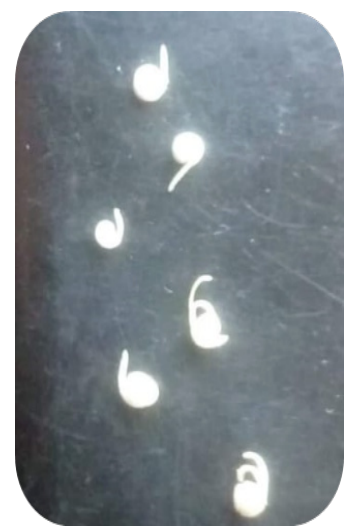

(B)

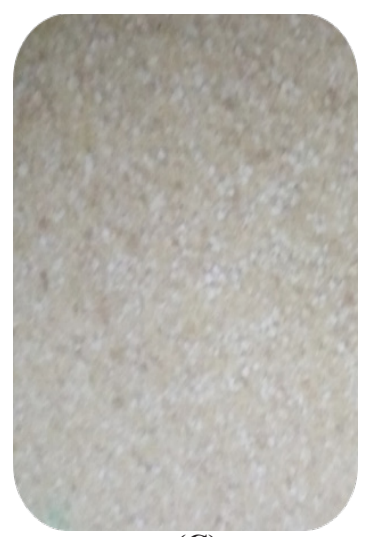

(C)

(A) Quinoa seeds

(B) Quinoa seeds after germination

(C) Quinoa seeds after dried and crushed

Note: the photo were taken by the author

Egypt. J. Food. 47, No. 2 (2019) 


\section{Nutritional characteristics}

Chemical composition

Quinoa (Chenopodium quinoa Willd.) was chemically analyzed for moisture, fat, crude protein, crude fiber, and ash, according to methods of (A.O.A.C., 2000). Total carbohydrates were estimated by difference. Whereas, the energy c calculated by the Atwater factor of 4, 9 and 4 for proteins, fats, and carbohydrates, respectively (Chaney, 2006).

Total Minerals of Fe and $\mathrm{Zn}$ were extracted by wet acid-digestion method, using mixture of nitric acid and perchloric acid (HNO: HClO, 5: $1 \mathrm{w}: \mathrm{v})$. The total $\mathrm{Fe}$ and $\mathrm{Zn}$ in the digested solution were measured by atomic absorption spectrophotometry (Thermo Elmental, 300VA, UK) (Lindsey and Norwell, 1969).

\section{Vitamin $C$ analysis}

Spectrophotometr (Model No 6300, designed and made in UK by I en way LTD) was used to estimate vitamin $\mathrm{C}$ levels as described by (Anonymous, 1966), where ascorbic acid reduced the dye of 2, 6 -dichlorophenol endophenol.

\section{Carotene analysis}

In this research, carotenoids were analyzed by HPLC (reversed-phase) using water 600 system which provided with auto samples injector, degasser, pump in addition to water $996 \mathrm{UV}$ (visible photodiode array detector) operating at $450 \mathrm{~nm}$. Then, the data were saved and processed by Millennium 4.00 software (production of Waters, Stockholm, Sweden). The absorption spectra were recorded between $250-500 \mathrm{~nm}$ (Rodriguez-Amaya, 1997).

\section{Experimental design}

Thirty male albino rats of Sprague Dawely strain weighing an average of $(150 \pm 10 \mathrm{~g})$ were used in the study and obtained from Vaccine and Immunity Organization, Helwan Farm, Cairo, Egypt. After the adaptation period of seven days, rats were randomly divided into two main groups; the first group which is the control negative had 6 rats that were fed on basal diet which composed of $12 \mathrm{~g}$ of casein $(85 \%$ protein); corn oil ( $10 \%$ fat ); minerals mixture ( $4 \%$ minerals); vitamins mixture ( $1 \%$ vitamins ); cellulose ( $4 \%$ fiber); and corn starch (71\% starch), and water supply was given ad-libitum and checked daily. The second group ( $\mathrm{n}=24$ rats), divided into four subgroups each group had 6 rats, one kept as a control positive and fed on basal diet, the other three groups were fed on basal diet supplemented with quinoa seeds at $50 \mathrm{~g} \mathrm{~kg}^{-1}, 100 \mathrm{~g} \mathrm{~kg}^{-1}$ and $150 \mathrm{~g}$ $\mathrm{kg}^{-1}$, respectively. Feeding experiment continued for four weeks, then those four subgroups of rats were injected with $(0.1 \%)$ nicotine sulfate $\left(3.5 \mathrm{mg} \mathrm{kg}^{-1}\right.$ body weight per day) subcutaneously for 15 days (Mandal et al., 2004).

\section{Biological evaluation}

During the experimental period, feed intake, body weight gain (BWG\%), and feed efficiency ratio (FER) was recorded every week. After sacrificed organ weight relative to body weight $\%$ were calculated as described by Chapman et al., (1959). Liver, Spleen, Lungs, and heart were removed from each rat, carefully washed with saline solution, dried with filter paper and weighted based on Drury and Wallington (1980).

\section{Biochemical analysis}

At the end of the experiment (after $24 \mathrm{hr}$. of the last injection) rats were fasted overnight prior to sacrificing under ether anesthesia. Blood samples were collected from the hepatic portal vein. Each sample was placed in a dry clean centrifuge tube. To separate the serum, blood samples were centrifuged for $10 \mathrm{~min}$. at 3000 revolutions per minute. The analysis was performed at the Medical College Laboratory, El-Zgazig University, Egypt. Serum was carefully separated into dry, clean Wasserman tubes using a Pasteur pipette, then kept frozen at $-20 \mathrm{C}^{\circ}$ till analysis. Serum total cholesterol (T.C) was determined in the serum as described by Allain et al., (1974). Serum triglycerides (T.G) were determined in the serum as described by Trinder and Ann (1969). Serum high-density lipoprotein cholesterol (HDL-C) was determined in the serum by the method of Lopes et al., (1977). Serum very low-density lipoprotein cholesterol (VLDL-C) and Serum low-density lipoprotein cholesterol (LDL-C) were calculated using equation 1() according to Friedwald et al., (1972).

$$
\begin{gathered}
\text { VLDL-C }=\frac{\mathrm{TG}(\mathrm{mg} / \mathrm{dL})}{5} \\
\text { LDL-C }=\text { Total Cholesterol }-[(\mathrm{VLDL}-\mathrm{C})+(\mathrm{HDL}-\mathrm{C})] . \\
\text { Eq. (1) }
\end{gathered}
$$

Atherogenic index (AI) was calculated by equation (2) according to Kikuchi -Hayakawa et al., (1998).

Atherogenic Index $=$ VLDL $+($ LDL/HDL $)$

Serum aspartate amino transaminase (AST), alanine amino transaminase (ALT) activities were 
determined as mentioned in Reitman and Frankel. (1957). Serum uric acid was measured in the serum by the method described of Barham and Trinder (1972) and Fossati et al. (1980), whereas serum urea nitrogen was determined in the serum based on Patton and Crouch (1977). Serum creatinine forms colored complex when reacting with alkaline Picrate. This reaction described by Faulkner and King (1976), Superoxide dismutase (SOD) activity was determined by the method of Kakkar et al. (1984). Malondialdehyde (MDA) was determined by the method of Okhawa et al. (1979).

\section{Statistical analysis}

Data were represented as means \pm standard deviation (SD). Differences were statistically analyzed by one-way analysis of variance (ANOVA test) using SPSS 16 software package and considered significant at $\mathrm{P}$ values $<0.05$.

\section{Results and Discussions}

\section{Chemical composition}

The chemical composition of quinoa seeds is presented in Table 1 (on dry weight basis per $100 \mathrm{~g}$ ). It is noticed from the data that fat, protein, carbohydrate, fiber, and moisture representing 6.03, $14.08,63.53,7.0$, and $13.28 \%$ respectively, while energy representing $364.71 \mathrm{kcal}$. Several studies stated the high biological value of quinoa, mainly high protein percentage in its seeds ( Miranda et al., 2013), dietary fiber and starch content of about 28.7, 13 and 60 respectively ( Repo and Serna, 2011), and lipid content of $4.5-8.7 \%$ divided as: $4 \%$ $\alpha$-linoleic, $24 \%$ oleic, and $54 \%$ linoleic. In addition, quinoa seeds contained $2.35 \%$ ash, $4.25 \mathrm{mg} 100$ $\mathrm{g}^{-1} \mathrm{Fe}$, and $2.9100 \mathrm{~g}^{-1} \mathrm{Zn}$, this may be because of its richness in minerals. Jancurová et al. (2009) and USDA (2013a) found that quinoa is also an excellent source of riboflavin, folacin, both alpha, and gamma tocopherols and thiamine. Comparing to other cereals, it has high concentrations of potassium, phosphorus, calcium, copper, and magnesium in addition to iron, zinc as mentioned above. The results in Table 1 also showed that the total phenolic of quinoa seeds represents $22.12 \mathrm{mg}$ Vit. C, $2.44 \mathrm{mg}$ Vit. E and $167 \mathrm{mg}$ Carotene. As well total phenol compound equivalent $/ 100 \mathrm{~g}$ of gallic acid is $319 \mathrm{mg}$; while total flavonoids compound equivalent/100 $\mathrm{g}$ of quercetin is $187 \mathrm{mg}$. Dini et al. (2010) stated that quinoa has been widely used because of its health benefits. Álvarez-Jubete et al. (2010) reported that quinoa seeds have significant amounts of bioactive components, such as vitamin C, polyphenols, carotenoids, betaines, fagopyritols, squalene, ecdysteroids, and phytosterols. Various bioactivities of these phenolic compounds are responsible for the chemopreventive properties of quinoa seeds (e.g., antioxidant, anti-inflammatory effects, anticarcinogenic, or antimutagenic). Forthrmore Gawlik-Dziki et al. (2013) added that quinoa seeds consist of enlarging quantities of bioactive components, such as sinapinic acid, gallic, ferulic, isorhamnetin, routine and kaempferol .

Bhargava et al. (2006) mentioned that the quinoa leaves contain a significant amount of proteins (27$30 \mathrm{~g} / \mathrm{kg})$, fiber $(1.9 \%)$, ash $(3.3 \%)$, vitamin E (2.9 $\mathrm{mg} \alpha \mathrm{TE} / 100 \mathrm{~g})$, vitamin $\mathrm{C}(1.2-2.3 \mathrm{~g} / \mathrm{kg})$, nitrates $(0.4 \%)$, and sodium $(289 \mathrm{mg} / 100 \mathrm{~g})$. However, they also reported that a number of "anti-nutritional" factors have been obviously found in its seeds such as phytic acid tannins, saponins, and protease inhibitors. Although, there is increasing proof about health useful effects of saponin for example, as hypocholesterolemic and anti-carcinogenic effects) (Kuljanabhagavad et al., 2008 and Álvarez- Jubete et al., 2010). Thus, soaking and germination of quinoa for removing anti-nutritional components in grains including saponins has widely been found in the literature (Chauhan et al., 1992 and Ruales \& Nair, 1993b).

TABLE 1. Quinoa seeds chemical composition of (value per $100 \mathrm{~g}$ ).

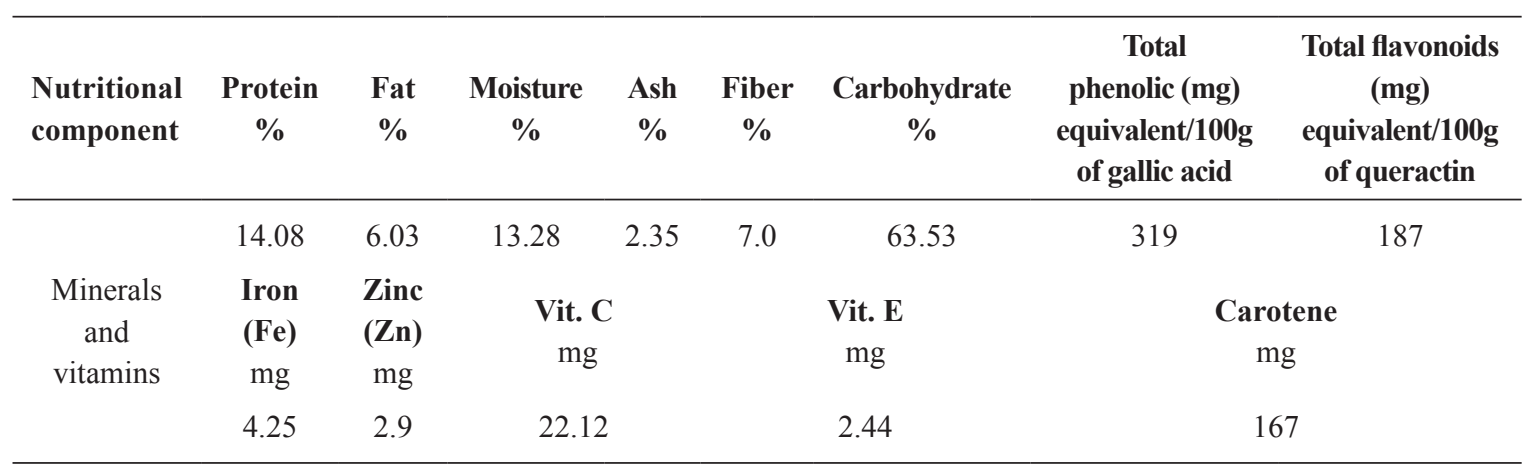




\section{Biological evaluation of investigated rats}

Feed intake (FI), body weight gain g (BWG) and Feed efficiency ratio (FER) of injected rats by nicotine are shown in Table 2. The data revealed that FI of injected rats was declined significantly than these of negative control rats at $5 \%$ quinoa seeds, while it was insignificant at 10 and $15 \%$ quinoa seeds. The positive control showed the lowest value of FI and indicated from the table. On the other hand, BWG showed the lowest significant value at the positive control treatment followed by $5 \%$ quinoa seeds. FER recorded the lowest significant value at positive control followed by $5 \%$ and 10 quinoa seed, with insignificant difference between $5 \%$ and $10 \%$ as presented in Table 2. This indicates that quinoa seeds can be used as a constituent in regimens for losing increased weight and obesity treatment.

Velarde-Salcedo et al. (2012) investigated and revealed the ability of quinoa seed peptide to prevent the activation of dipeptidase dipeptidyl enzyme, in addition, to conduct the effects of this peptide in lipid accumulation in adipocyte rats cultures. Simnadis et al. (2015) investigated physiological effect of consuming quinoa seeds to decrease weight gain and improve lipids profile. These physiological effects were attributed to the presence of protein, saponin, and 20- hydroxyecdysone in quinoa seeds, in addition to increasing the permeability of intestinal epithelial cell, decrease the capacity to nutrients active absorption for development and growth of animals. The results of this study were in agreement with Abdallah and Bakry (2014) who suggested that the loss of BWG may be increasing the degradation of fat and protein due to the immediate nicotine effect. It is notified that organic solvent exposure reduced FI and BWG in rats and mice, this effect may be resulting from appetite loss. Mechanisms of nicotine smoking are to prevent the increase in predicted compensatory in caloric intake and to reduce body weight by increment expenditure of energy). Nicotine also increases the levels of central neural system of serotonin, norepinephrine, and dopamine such as bupropion, sibutramine and phentermine which repress the facilitate of weight loss and appetite (Ioannides-Demos et al., 2011)

\section{Relative organs weight}

The results of relative weight of liver, spleen, lungs, and heart to body weight in rats' injected nicotine after feed on quinoa seeds are shown in Table 3. Liver weight was significantly increased at $(\mathrm{p}<0.05)$ in positive group when compared to normal rats' group $3.33 \pm 0.32$ and $2.45 \pm 0.3 \%$, respectively). However, there is insignificant difference between all quinoa treatments. The best result found in quinoa seeds (10\%) $2.59 \pm 0.40 \%$. On contrast, Spleen, lungs and heart weights were significantly declined at $(p<0.05)$ in rats that injected by nicotine comparing to normal rats' group. The best results recorded in $10 \%$ quinoa seeds as $0.51 \pm 0.08,0.84 \pm 0.12 \%$, respectively in spleen and lungs, while, it was at $5 \%$ quinoa seeds in heart. Generally, all quinoa seeds treatments had significant increment of organ weights compared to the positive group.

TABLE 2. Protective effect of quinoa seeds on feed intake, body gained weight (BWG) and feed efficiency ratio (FER).

\begin{tabular}{lccc}
\hline Groups & FI (g)/day & BWG (g) & FER \\
\hline Control (- ve) & $19.68 \pm 0.27^{\mathrm{a}}$ & $11.82 \pm 0.12^{\mathrm{a}}$ & $0.08 \pm 0.02^{\mathrm{a}}$ \\
Control (+ ve) & $16.45 \pm 0.28^{\mathrm{c}}$ & $-20.71 \pm 0.12^{\mathrm{e}}$ & $-0.06 \pm 0.02^{\mathrm{c}}$ \\
Quinoa seeds (5\%) & $18.08 \pm 0.45^{\mathrm{b}}$ & $-8.45 \pm 0.20^{\mathrm{d}}$ & $-0.02 \pm 0.01^{\mathrm{d}}$ \\
Quinoa seeds (10\%) & $18.10 \pm 0.17^{\mathrm{a}}$ & $-4.24 \pm 0.07^{\mathrm{c}}$ & $-0.01 \pm 0.02^{\mathrm{d}}$ \\
Quinoa seeds (15\%) & $18.06 \pm 0.12^{\mathrm{a}}$ & $6.99 \pm 0.05^{\mathrm{b}}$ & $0.01 \pm 0.00^{\mathrm{b}}$
\end{tabular}

$\overline{\text { Means with dissimilar letters (a, b, c, d, etc.) in the same column differ significantly at } \mathrm{p} \square 0.05 \text { by Duncan test, while those }}$ with similar letter completely or partially are non-significantly different. 
TABLE 3. Protective effect of quinoa seeds on organs weight percentage.

\begin{tabular}{lcccc}
\hline \multicolumn{1}{c}{ Groups } & Liver \% & Spleen \% & Lungs \% & Heart \% \\
\hline Control (- ve) & $2.45 \pm 0.3^{\mathrm{b}}$ & $0.71 \pm 0.31^{\mathrm{a}}$ & $0.94 \pm 0.19^{\mathrm{a}}$ & $0.52 \pm 0.07^{\mathrm{a}}$ \\
Control (+ ve) & $3.33 \pm 0.32^{\mathrm{a}}$ & $0.45 \pm 0.13^{\mathrm{b}}$ & $0.59 \pm 0.16^{\mathrm{c}}$ & $0.36 \pm 0.05^{\mathrm{c}}$ \\
Quinoa seeds (5\%) & $2.67 \pm 0.32^{\mathrm{b}}$ & $0.46 \pm 0.11^{\mathrm{b}}$ & $0.70 \pm 0.10^{\mathrm{bc}}$ & $0.45 \pm 0.07^{\mathrm{ab}}$ \\
Quinoa seeds (10\%) & $2.59 \pm 0.40^{\mathrm{b}}$ & $0.51 \pm 0.08^{\mathrm{ab}}$ & $0.84 \pm 0.12^{\mathrm{ab}}$ & $0.37 \pm 0.03^{\mathrm{bc}}$ \\
& & & \\
Quinoa seeds (15\%) & $2.76 \pm 0.35^{\mathrm{b}}$ & $0.50 \pm 0.10^{\mathrm{b}}$ & $0.83 \pm 0.08^{\mathrm{ab}}$ & $0.38 \pm 0.06^{\mathrm{bc}}$ \\
\hline
\end{tabular}

- Means with dissimilar letters ( $a, b, c$, d, etc.) in the same column differ significantly at $\mathrm{p} \leq 0.05$ by Duncan test, while those with similar letter completely or partially are non-significantly different

González et al. (2014) showed that quinoa seeds induced significantly the decrease in liver weight and it relatively increased the heart and kidney weighting. They showed also that the intake of quinoa seeds caused speed increase in vitamin $\mathrm{E}$ in the heart, liver, lungs, spleen, and kidneys and increase the antioxidant protection power of these organs in addition to their tissues. The results also accorded with Sreeparna et al. (2008) who studied the effect of nicotine to induced oxidative stress. They found a significant decrease in the antioxidant enzyme in liver, kidney, heart, lung, and spleen and elevated levels of protein oxidation, lipids peroxidation was not abled in nicotine treated group when compared to vehicle-treated group. This indicates that vit. $\mathrm{E}$ in quinoa seeds may act as supposed protective agent which can provide a new path for improving suitable drug therapy (Vega-Gálvez et al. 2010). The results also partially agree with Heijne et al. (2005) who observed a decrease of kidney and heart weights of injected nicotine rats compared to health rats' group. Hence, it would be observed as accurate liver changing which cannot be accorded to reduction of body weight. As well, the results accorded with Abdallah and Bakry (2014) who revealed that nicotine injection in rats caused a significant increase in liver weight compared to normal rats' group. The increasing enzyme expression of drug metabolism in liver cells could be the most important reason for relative increasing of liver weighting. On the other hand, the results of liver weight disagree with (Willis et al., 2014) who recorded a significant decrease in liver weights in nicotine group comparing to other rat groups. The metabolism troubles in rats resulted in nicotine management could cause weighting loss. Their results verified the findings of the study performed on nicotine to decrease the various organs weighting, inclusively the liver. Many studies confirmed that nicotine can affect relative organ weight, which increases the heart rate and cardiac work (Audrain-McGovern and Benowitz, 2011). This is because nicotine has negative impacts on many vital viscera organs such as these notified in smoker women (Iranloye and Bolarinwa, 2009).

\section{Biochemical analysis \\ Lipids profile}

Total cholesterol and triglyceride were determined for the protective effect of supplemented diets with quinoa seeds on rats' health and the results are presented in Fig. 1. The total cholesterol and triglyceride record the highest significant increase in positive control $\left(111.60 \pm 1.41\right.$ and $91.80 \pm 1.17 \mathrm{mg} \mathrm{dl}^{-1}$, respectively) while, it was low in negative control $\left(81.8 \pm 1.21\right.$ and $\left.73.8 \pm 1.00 \mathrm{mg} \mathrm{dl}^{-1}\right)$, respectively. Moreover, the rats fed on 5 and 10 $\%$ quinoa seeds were the best decreased when compared to positive control $5 \%$ quinoa seeds $(93.4 \pm 1.21$ and $85.63 \pm 0.80)$ and $10 \%$ quinoa seeds ( $92.6 \pm 2.42$ and $83.30 \pm 0.62) \mathrm{mg} \mathrm{dl}^{-1}$ respectively . 


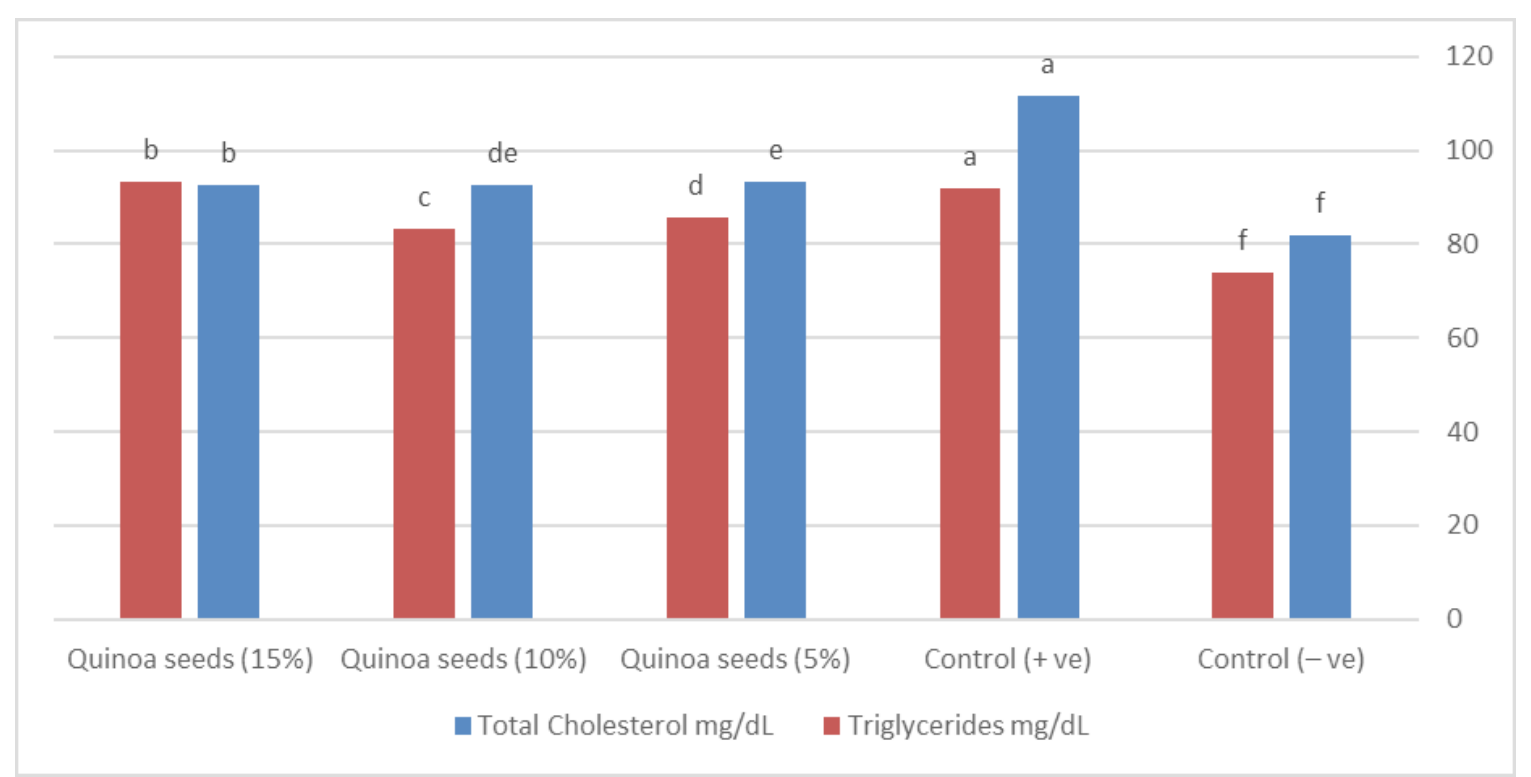

Fig. 1. Protective effect of quinoa seeds on total cholesterol (TC) and triglycerides (TG).

Using isolates protein obtained from quinoa seeds ( $>10 \%$ of cereal) has significantly declined the level of serum and total liver cholesterol in rats feed on lipid fortified diet (Takao et al., 2005). Moreover, using those quinoa isolates protein demonstrated an activity of bile acid bound in vitro in addition to modification of expressing in liver cell of 3-hydroxyl -3-methylglutaryl coenzyme A (HMG- CoA) - the critical enzyme for biosynthesizing of cholesterol. Those findings proposed prevention of increasing serum and cholesterol in liver of rats fed on diet comprised of quinoa isolates protein, which may cause the suppression of reabsorbed bile acid in the small intestines and synthesized cholesterol and its catabolism. other researches, that used flour or hydrolyzed proteins of quinoa, displayed that the bio-active property of quinoa seeds can have a significant reduction of blood pressure in mice (Ogawa et al., 2001 and Aluko and Monu, 2003). In-vivo researches used $3 \%$ concentricity of quinoa seeds crust like as complement diet as well elucidated significantly lowering of serum and cholesterol of liver level in rats (Aluko and Monu, 2003).

Lipoprotein fractions (LDL-C, $H D L-C$, $V L D L-C)$ and Atherogenic Index (AI)

Results in Table 4 explained plasma level of (VLDL, HDL, LDL and atherogenic index) of protective effect of quinoa seeds. Plasma lipoprotein fraction proved significantly decrease in HDL level. On contrast it showed significantly increase in VLDL, LDL levels and (AI) in positive control group $(39.33 \pm 1.03,18.36 \pm 0.23,85.30$ \pm 1.57 , and $\left.2.63 \pm 0.09 \mathrm{mg} \mathrm{dl}^{-1}\right)$ as compared to negative control group $(62.50 \pm 1.04,17.73$ $\pm 2.14,13.10 \pm 0.20$ and $\left.0.49 \pm 0.04 \mathrm{mg} \mathrm{dl}^{-1}\right)$. quinoa seeds $(15 \%)$ recorded the best result for an HDL level $\left(47.66 \pm 1.50 \mathrm{mg} \mathrm{dl}^{-1}\right)$ as compared to the positive control. Moreover, quinoa seeds $(5 \%)\left(26.24 \pm 1.58 \mathrm{mg} \mathrm{dl}^{-1}\right)$ recorded the highest result for LDL level compared to positive control group $\left(26.24 \pm 1.58 \mathrm{mg} \mathrm{dl}^{-1}\right)$. The best VLDL result showed in quinoa seeds (5\%) (13.92 \pm

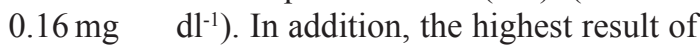
atherongenic index recorded in quinoa seeds (5\%) as $(0.71 \pm 0.04)$

Furthermore, the introducing of quinoa in the diet can reduce TG, LDL, TC, and the total serum protein levels, without declining in lipoproteins HDLs. These results proposed that quinoa seeds, in the regimen, can act as moderate preventative factor against possible changing induced by fructose consuming through reducing lipids peroxidation and improving antioxidant ability in blood serum. As well, it can reduce most of opposite effects caused by fructose in lipids profile (Pasko et al., 2010a, b). This study indicating the potential actions of quinoa as coadjutant factor in the treating of heart diseases because of declining of LDL-c and TC. It is known that high LDL-c concentrations relate to an increased risk of cardiovascular. Thus, quinoa seeds absorption regulate cholesterol concentration, as display by De Carvalho et al. (2014). 
TABLE 4. Protective effect of quinoa seeds on lipoproteins fraction (VLDL-C, LDL-C, HDL-C) \& atherogenic index (AI).

\begin{tabular}{lcccc}
\hline Groups & HDL-C $\left(\mathbf{m g ~ d l}^{-1}\right)$ & LDL-C $\left(\mathbf{m g ~ d l}^{-1}\right)$ & VLDL-C $\left(\mathbf{m g ~ d l}^{-1}\right)$ & AI \\
\hline Control (- ve) & $62.50 \pm 1.04^{\mathrm{a}}$ & $17.73 \pm 2.14^{\mathrm{e}}$ & $13.10 \pm 0.20^{\mathrm{f}}$ & $0.49 \pm 0.04^{\mathrm{f}}$ \\
Control (+ ve) & $39.33 \pm 1.03^{\mathrm{f}}$ & $85.30 \pm 1.57^{\mathrm{a}}$ & $18.36 \pm 0.23^{\mathrm{a}}$ & $2.63 \pm 0.09^{\mathrm{a}}$ \\
Quinoa seeds (5\%) & $56.16 \pm 1.16^{\mathrm{bc}}$ & $26.24 \pm 1.58^{\mathrm{d}}$ & $13.92 \pm 0.16^{\mathrm{d}}$ & $0.71 \pm 0.04^{\mathrm{de}}$ \\
Quinoa seeds (10\%) & $50.33 \pm 1.21^{\mathrm{d}}$ & $31.70 \pm 2.57^{\mathrm{c}}$ & $14.46 \pm 0.12^{\mathrm{c}}$ & $0.91 \pm 0.06^{\mathrm{c}}$ \\
Quinoa seeds (15\%) & $47.66 \pm 1.50^{\mathrm{e}}$ & $36.08 \pm 2.02^{\mathrm{b}}$ & $16.08 \pm 0.23^{\mathrm{b}}$ & $1.09 \pm 0.07^{\mathrm{b}}$ \\
\hline
\end{tabular}

Means with dissimilar letters ( $\mathrm{a}, \mathrm{b}, \mathrm{c}, \mathrm{d}$, etc.) in the same column differ significantly at $\mathrm{p} \leq 0.05$ by Duncan test, while those with similar letter completely or partially are non-significantly different.

Whitehead et al. (2014) suggested that protein exists in quinoa seeds decline the liver cholesterol synthesis by bile acid reabsorption. That was supported by the finding that bile acid excretion was raised, and expressions of hepatic HMG-CoA reductase was decreased between rat feed on quinoa seeds. This is the same mechanism that another food compound such as $\beta$-glucans effects on reducing cholesterol levels.

According to Chattopadhyay et al. (2008), nicotine made toxicity in lipids profile, in serum, and lipids peroxidation, in serum and ovary tissue, under protein-limited diet comparing to that of normal protein diet. These results agree with Sreeparna et al. (2008) who studied the nicotine effect for inducing oxidative stress. They conducted a significant increase of lipids peroxidation in a group treated with nicotine comparing to the normal control group. As well, vit. E in quinoa seeds significantly reduced the lipid peroxidation.

\section{Liver enzymes}

Liver enzymes expressed as SGOT and SGPT $\left(\mathrm{U} \mathrm{L}^{-1}\right)$ of all groups are shown in Table 5. The mean values of positive group injected with nicotine were significantly higher at $(\mathrm{p}<0.05)$ in GPT enzyme compared to normal rats group $\left(49.33 \pm 3.26\right.$ and $35.60 \pm 1.61 \mathrm{U} \mathrm{L}^{-11}$ respectively). The best results recorded in $5 \%$ quinoa seeds $(5 \%)$, where the SGPT is significantly lower; 38.2 $\pm 1.04 \mathrm{U} \mathrm{L}^{-1}$. The serum levels of SGPT enzyme, in negative control group, were significantly more than its corresponding in positive group at $(P<0.05)\left(50.8 \pm 0.75\right.$ and $67.1 \pm 0.78 \mathrm{U} \mathrm{L}^{-1}$ respectively). Treated groups with $5 \%$ quinoa seeds of $57.73 \pm 1.53 \mathrm{U} \mathrm{L}^{-1}$ had a significant decrease in serum levels. Hence, treated groups with quinoa seeds revealed the greatest decline in enzyme levels in the serum when comparing to positive control group.

The results were in agreement with RepoCarrasco (2010), who assessed the antioxidant role of quinoa seeds. Their results showed that the enzyme activities such as SPGT and SGOT were significantly decreased in rats fed on quinoa seeds. The liver is vital organ to peroxidative injury because it has high amount of oxidizable component. The increment of oxidative stress in liver tissues and the subsequent decreasing in resulting antioxidant capacity of the tissues when attacking cells injury to the liver cells with the release of enzymes into the bloodstream and destruction of their cell's velum. Some bioactive components of vitamins in quinoa seeds are serious because its working work as antioxidants at the cell velum levels, for example magnesium, selenium, phytosterols, folic acid, and tocopherols (Repo-Carrasco., 2003).

The results of this study accorded with El Zayadi (2006) who stated that nicotine resulted from heavy cigarette smoking increased the hazard of developing chronically diseased liver and hepatocellular carcinoma (HCC). Furthermore, nicotine produces pro-inflammatory cytokins that could be involved in liver cell damage. As well, liver toxicity leads to reduce liver size because of chronic or acute liver injury as a consequence of cell loss. 
TABLE 5. Protective effect of quinoa seeds on plasma liver enzymes.

\begin{tabular}{|c|c|c|}
\hline Groups & SGPT (U L L $\left.{ }^{-1}\right)$ & SGOT $\left(\mathbf{U ~ L ~}^{-1}\right)$ \\
\hline Control (- ve) & $35.60 \pm 1.61^{\mathrm{c}}$ & $50.8 \pm 0.75^{\mathrm{f}}$ \\
\hline Control (+ ve) & $49.33 \pm 3.26^{\mathrm{a}}$ & $67.1 \pm 0.78^{\mathrm{a}}$ \\
\hline Quinoa seeds (5\%) & $38.2 \pm 1.04^{\mathrm{bc}}$ & $57.73 \pm 1.53^{\mathrm{c}}$ \\
\hline Quinoa seeds (10\%) & $43.83 \pm 1.16^{b}$ & $64.6 \pm 1.16^{\mathrm{c}}$ \\
\hline Quinoa seeds (15\%) & $44.4 \pm 2.52^{b}$ & $71.8 \pm 1.63^{\mathrm{b}}$ \\
\hline
\end{tabular}

_Means with dissimilar letters (a, b, c, d, etc.) in the same column differ significantly at $\mathrm{p} \leq 0.05$ by Duncan test, while those with similar letter completely or partially are non-significantly different.

\section{Kidney function}

The data in Table 6 show the protective effect of supplemented diets with quinoa seeds on kidney function; uric acid, urea, and creatinine. It is noticed that nicotine injection not only led to affecting the liver function but also the kidney functions as implied by the increase of plasma creatinine, urea, and uric acid. Plasma uric acid, urea, and creatinine of the positive control group showed a significant increase $(2.00 \pm 0.16,59.83$ \pm 1.16 and $1.20 \pm 0.14 \mathrm{mg} \mathrm{dl}^{-1}$, respectively) as compared to the normal control group $(1.40 \pm 0.06$, $39.00 \pm 0.89$ and $0.83 \pm 0.12 \mathrm{mg} \mathrm{dl}^{-1}$, respectively). Quinoa treated groups had significantly decreased the plasma levels of uric acid. The best results in the level of uric acid were found in treated group with $5 \%$ quinoa seeds group; $1.46 \pm 0.08 \mathrm{mg} \mathrm{dl}^{-1}$ ). The best results of plasma levels of urea in treated groups were found also in 5\% quinoa seeds group; $\left.42.20 \pm 1.16 \mathrm{mg} \mathrm{dl}^{-1}\right)$. On the other hand, the best results of plasma creatinine levels of treated groups were found in $10 \%$ quinoa seeds group; $\left.0.88 \pm 0.20 \mathrm{mg} \mathrm{dl}^{-1}\right)$.

The result of this study agrees with the assumption of dietary fiber improves kidney function level (Altunkaynak, et al., 2008). Some bioactive ingredients of quinoa vitamins are important because of their working as an antioxidant in kidney cell membranes, such as selenium, magnesium, phytosterols, folic acid and tocopherols which are supposed to have antioxidant anti-carcinogenetic properties, or work as antiinflammatory (Repo-Carrasco., 2003).
The kidney parameter such as uric acid, creatinine, and urea in mice feed on both of lipid and basal diet were low of about 42.0, 1.13, and $5.73 \mathrm{mg} \mathrm{dl}^{-1}$ in obese rat set to $16.0,0.5$, and $2.46 \mathrm{mg} \mathrm{dl}^{-1}$ in rat set feed on $60 \%$ quinoa seeds and $15 \%$ different fibers of defatted soybean and carrot powder. The results recommend that quinoa seeds work as antiobesity activities and could be used as a nutritional complement for treating and preventing disorders of obese and obesity (Hejazi, 2016)

The liver metabolizes $80-90 \%$ of nicotine, but lung and kidneys metabolize the small amount of it. Yildiz (2004) reported that the kidney functions were affected as revealed from the increase of plasma uric acid, urea and creatinine but in a small amount. In mammals, glycine betaine as byproduct from quinoa seeds acts as osmolytes in the internal medullary of the kidney. However, glycine betaine in humans may be easily absorbed through dietary assimilation or endogenous creating in the liver through choline catabolism. In human plasma, glycine betaine concentration is high regulating, although its concentration decreases in kidney urinary excretion and it is high in diabetic patients, and kidney disease patients (Dini et al. 2006). Glycine betaine absorption may decrease the plasma level of homocysteine inpatient suffers from homocystinuria and patient of chronic kidney failures with hyperhomocysteinemia (Tang et al., 2002). 
TABLE 6. Protective effect of quinoa seeds on kidney function.

\begin{tabular}{|c|c|c|c|}
\hline Parameters & Uric acid (mg / dl) & Urea (mg / dl) & Creatinine (mg / dl) \\
\hline Control (- ve) & $1.40 \pm 0.06^{\mathrm{e}}$ & $39.00 \pm 0.89^{b}$ & $0.83 \pm 0.12^{f}$ \\
\hline Control (+ ve) & $2.00 \pm 0.16^{\mathrm{a}}$ & $59.83 \pm 1.16^{\mathrm{a}}$ & $1.20 \pm 0.14^{\mathrm{a}}$ \\
\hline Quinoa seeds (5\%) & $1.46 \pm 0.08^{\mathrm{d}}$ & $42.20 \pm 1.16^{b}$ & $0.91 \pm 0.07^{\mathrm{d}}$ \\
\hline Quinoa seeds (10\%) & $1.61 \pm 0.09^{\mathrm{c}}$ & $47.16 \pm 1.16^{b}$ & $0.88 \pm 0.20^{\mathrm{e}}$ \\
\hline Quinoa seeds (15\%) & $1.76 \pm 0.05^{b}$ & $43.00 \pm 1.67^{b}$ & $1.01 \pm 0.19^{\mathrm{b}}$ \\
\hline
\end{tabular}

Means with different letters (a, b, c, d, etc.) in the same column differ significantly at $\mathrm{p} \leq 0.05$ by Duncan test, while those with similar letter completely or partially are non-significantly different.

\section{Antioxidant enzyme marker}

Table 7 shows the antioxidant activities as a plasma superoxide dismutase (SOD) of health rats' diet with quinoa seeds. It is clear that, due to nicotine injection, the activities of plasma SOD significantly declined; this loss of antioxidant enzymes as a result of liver disorders. SOD enzyme of 5, 10 and $15 \%$ quinoa seeds groups recorded significant decrease of $13.00 \pm 0.89$, $12.83 \pm 0.82$ and $11.34 \pm 1.20 \mathrm{u} \mathrm{ml}^{-1}$, respectively compared to positive control group of $8.14 \pm 0.62$ $\mathrm{u} \mathrm{ml}^{-1}$ ). As well, treated groups had a significant increase in SOD level. The highest increase was recorded at $5 \%$ quinoa seeds.

De Carvalho et al. (2014) reported a potential benefit of quinoa seeds consumption against oxidative stress. They investigated the effect of consuming 25 g per day of quinoa seeds for 28 days on the signs of oxidative stress, fractions of cholesterol and cholesterol in postmenopausal women group. The lipid peroxidation process works an important task in the pathogenesis of many human diseases. Decreasing activities of antioxidant enzymes such as SOD could be attributed to the crushing influences of free radicals, as shown by the elevated levels of lipids peroxidation. The start of lipid peroxidation is done in most cases by free radicals such as hydroxyl radicals, superoxide, or another oxygen (O) reactive species such as $\mathrm{H}_{2} \mathrm{O}_{2}$ that cause damage in cell, etc. Increasing the level of lipids peroxidation in cell of intraperitoneal rats treated by nicotine have shown by Tang et al. (2015b).

Lipid peroxidation assay of liver tissue

Data in Table 8 demonstrated the protective effect of quinoa seeds on malondialdehyde (MDA) as lipid peroxidation assay of liver tissue. There was a significant increase in MAD level in positive control as compared to negative control $(88.76 \pm 1.01$ and $32.29 \pm 0.62 \mathrm{nmol}$, respectively). Treated groups with quinoa seeds had a significant decrease in MAD level. The best result showed in group 5\% quinoa seeds $48.39 \pm$ 0.79 nmol.

Also, these results were in an agreement with Abdallah and Bakry (2014), who showed plasma oxidative stress markers as MDA (nmol/g protein) were noticed in homogenate livers of all groups. MDA for nicotine rats' group was significantly higher compared to normal rats' group. Consequently, the right cases of liver antioxidant defense systems are of large important regarding health servicing. Increased reactive oxygen metabolite, especially hydroxyl radical, effect on phospholipid compounds of unsaturated fatty acid of cells to produce malondialdehyde and effect of lipids peroxidation production (Goel et al., 2005). This study agrees with the result of this research since nicotine has notified to induce oxidative stress, as display with enhanced MDA producing.

The total carotenoids content of white, black and red quinoa seeds is $11.87,17.61$ and $14.97 \mu \mathrm{g}$ $\mathrm{g}^{-1}$ respectively. Carotenoid is an organic pigment in the chloroplast and plant chromoplast. Its role in red, yellow and orange plants is saving chlorophyll from photo-damage. It works as an antioxidant in the humans' body (Fardet, 2010). In addition, quinoa has at least 23 phenolic compounds. Ferulic acid and quercetin are the most abundant phenols (Tang et al., 2015b). Repo-Carrasco. (2010) stated that phenol structural units in quinoa act as antioxidant components in the human diet. As well, the vitamins content in quinoa seeds considers a good source because they work as antioxidant at the cell velum levels, which save fatty acid damage of the cell velum caused by free radical (RepoCarrasco., 2010). 
TABLE 7. Protective effect of quinoa seeds on plasma superoxide dismutase (SOD), and malondialdehyde (MDA) of liver tissue.

\begin{tabular}{|c|c|c|c|}
\hline Groups & Parameters & SOD ( U/ml ) & MAD (nmol/g. tissue) \\
\hline Control (- ve) & & $16.14 \pm 0.80^{\mathrm{a}}$ & $32.29 \pm 0.62^{\mathrm{e}}$ \\
\hline Control (+ ve) & & $8.14 \pm 0.62^{\mathrm{e}}$ & $88.76 \pm 1.01^{\mathrm{a}}$ \\
\hline Quinoa seeds (5\%) & & $13.00 \pm 0.89^{\mathrm{b}}$ & $48.39 \pm 0.79^{d}$ \\
\hline Quinoa seeds (10\%) & & $12.83 \pm 0.82^{\mathrm{c}}$ & $54.20 \pm 2.40^{\mathrm{c}}$ \\
\hline Quinoa seeds (15\%) & & $11.34 \pm 1.20^{\mathrm{d}}$ & $69.33 \pm 1.48^{b}$ \\
\hline
\end{tabular}

Means with different letters ( $a, b, c, d$, etc.) in the same column differ significantly at $\mathrm{p} \leq 0.05$ by Duncan test, while those with similar letter completely or partially are non-significantly different.

\section{Conclusion}

The results from this study focus on the protective role of quinoa seeds at different concentrations against nicotine injection as a contamination source resulting from smoking and their results in various degrees of injury to internal organs by inducing oxidative stress and lipid peroxidation of liver tissues. Thus, the study confirmed the possibility of using quinoa seeds in diets to protect the internal organs functions from damage by nicotine. This is because of useful nutritional value of quinoa seeds that have recently highlighted worldwide. The nutritional benefits of its seeds have remarkably known for its high protein quality (good source in vital amino acids), as well, for their content of carbohydrates, fat, vitamin and mineral components. Also, it is considered as a rich source for dietary fiber and other bioactive component, such as triterpenoids and polyphenols. In this context, many studies adopt different biological approaches that have assured the bioactive components in quinoa seeds, its role as an anti-cancer, hypocholesterolemia, anti-inflammatory and antioxidant. Similarly, it is being safer for consuming by patients suffering from coeliac diseases. Consequently, this study recommends the potential use of quinoa seeds as nutritional supplements that may be enriched diets and reduce the risk factors of chronic diseases. This may open new perspectives for using quinoa seeds in biomedicine pharmacotherapy.

\section{References}

A.O.A.C., (2000) Official Methods of Analysis, 17 Ed,. Association of Official Analytic Chemists International. Arlington, Virginia, USA. Abdallah, A. and Bakry, S. (2014) Hepatoprotective and antioxidant activity of wheat germ oil against nicotine induced oxidative stress advances in biological research, 8 (6), 289-297.

Allain, C.C.; Poon, L.S. and Chan, C.S. (1974) "Enzymatic determination of serum total cholesterol". Clin. Chem., 20 , 470-475.Altunkaynak, M.E., E. Özbek, B.Z. Altunkaynak, I. Can, D. Unal and B. Unal (2008) The effects of high-fat diet on the renal structure and morphometric parametric of kidneys in rats. Journal of Anatomy, 6, 845-852.

Aluko RE and Monu E, (2003) Functional and bioactive properties of quinoa seed protein hydrolysates. $J$. Food Sci. 68,1254-1258.

Álvarez -Jubete, L., Arendt, E.K. \& Gallagher, E. (2010) Nutritive value of pseudocereals and their increasing use as functional gluten free ingredients. Trends in Food Science and Technology, 21, 106-113.

Anonymous, (1966) Methods of Vitamin Assay. Interscience Publishers, New York, USA, pp: 237-307.

Audrain-McGovern, J. and Benowitz, NL. (2011) Cigarette Smoking, Nicotine, and Body Weight. Clin Pharmacol Ther. 2011 Jul; 90(1): 164-168. Bandyopadhyaya, G.; Sinha, S., Chattopadhyay, B.D. and Chakraborty, A. (2008): Protective role of curcumin against nicotine induced genotoxicity on rat liver under restricted dietary protein. Eur. $J$. Pharmacol. 588, 151-157.

Banerjee, S. ; Bandhyopadhyaya, G. ; Chattopadhyay, K. and Chatto padhyay, B.D. (2010) Amelioration of nicotine induced damage of blood cells in protein malnourished female rats by curcumin. Int. J. Pharmacol. 6, 409-420. Barham, D. and Trinder, P. (1972) "Quantitative enzymatic colorimetric determination of uric acid in serum, plasma or urine “. Analyst, 97, 142. 
Bhargava, A., Shukla, S. \& Ohri, D. (2006) Chenopodium quinoa -an Indian perspective. Industrial Crops and Products, 23, 73-87.

Brady, K., Ho, Ch-T., Rosen, R.T., Sang, S. \& Karwe, M.V. (2007) Effects of processing on the nutraceutical profile of quinoa. Food Chemistry, 100, 1209-1216.

Chaney, S.G., (2006) Principles of Nutrition I: Macronutrients. In: Devlin, T.M. (Ed.) Textbook of Biochemistry, with Clinical Correlation, 6th ed. John Wiley and sons, New York, pp. 1071-1090.

Chapman, D.G.; Castilla, R. and Campbell, J.A. (1959) Evaluation of protein in food. I. A method for the determination of protein efficiency ratio. Can. J. Biochem. Physiol., 37, 679-689.

Chattopadhyay, K. and B.D. Chattopadhyay, (2008) Effect of nicotine on lipid profile, peroxidation \& antioxidant enzymes in female rats with restricted dietary protein Indian J. Med. Res., 127: 571-576. Chauhan, G.S., Eskin, N.A.M. \& Tkachuk, R. (1992) Nutrients and antinutrients in quinoa seed. Cereal Chemistry, 69 (1), 85-88.

De Carvalho F.G., Ovidio P.P., Padovan G.J., Jordao Junior A.A., Marchini J.S. et al. (2014) Metabolic parameters of postmenopausal women aier quinoa or corn flakes intake- a prospective and doubléblind study. Int. J. Food Sci. Nutr. 65, 380-385.

Dini I., Tenore G.C., Trimarco E., Dini A. (2006) Two novel betaine derivatives from Kancolla seeds (Chenopodiaceae). Food Chemistry, 98, 209-213.

Dini, I., Tenore, G.C. \& Dini, A. (2010) Antioxidant compound contents and antioxidant activity before and after cooking in sweet and bitter Chenopodium quinoa seeds. LWTFood Sience and Technology, 43, 447-451.

Drury , R .A. and Wallington , E.A. (1980) Carton's histological technique. 5th Ed., Oxford University. UK.El -Zayadi, AR. (2006) Heavy smoking and liver .World J.Gastroenterol. 12 (38), 6098-6101

El-Sokkary, G.H.; Cuzzocrea, S. and Reiter, R.J. (2007) Effect of chronic nicotine administration on the rat lung and liver: Beneficial role of melatonin. Toxicology, 239, 60-67.

Fardet, A. (2010) New hypotheses for the healthprotective mechanisms of whole-grain cereals: what is beyond fibre? Nutr. Res. Rev. 23, 65-134.

Faulkner, N.R. and King, J.W. (1976) Fundamental of clinical chemistry. 2nd ed. Tietz Editor. Saunders
Philadelhia, 994-998.

Fossati , P; Prencipe, L. and Berti, G. (1980) Enzymatic colorimetric method for determination of uric acid in serum. Clin. Chem., 26 (2), 227-273.

Friedwald, W.T.; Leve , R.I. and Fredrickson, D.S. (1972) Estimation of the concentration of lowdensity lipoprotein separated by three different methods. Clin. Chem., 18: 499-502.

Gawlik - Dziki, U., Świeca, M., Sułkowski, M., Dziki, D., Baraniak, B. \& Czyż, J. (2013) Antioxidant and anticancer activities of Chenopodium quinoa leaves extracts - In vitro study. Food and Chemical Toxicology, 57, 154-160.

Goel, A.; Dani, V. and Dhawan, D.K. (2005) Protective effects of zinc on lipid peroxidation, antioxidant enzymes and hepatic histoarchitecture in chlorpyrifos induced toxicity. Chem. Biol. Interact., 156, 131-140.

González Martín MI, Wells Moncada G, Fischer S, Escuredo O (2014): Chemical characteristics and mineral composition of quinoa by nearinfrared spectroscopy. J. Sci. Food Agric. 94, 876-881.

Heijne, W.H.; Jonker, R.H.; Stierum, B.; Ommen, D. and Groten, J. (2005) Toxicogenomic analysis of gene expression changes in rat's liver after a 28-day oral benzene exposure. Mutat. Res., 575, 85-101.

Hejazi , Maha .A. (2016): Preparation of different formulae from quinoa and different sources dietary fiber to treat obesity in rats. Nat Sci.,14 (2), 55-65. doi: 10.7537 / marsnsj14021608.

Ioannides-Demos L.L., Piccenna L., McNeil J.J. (2011) Pharmacotherapies for obesity: past, current, and future therapies. J. Obes. 2011; 2011 : 179674.

Iranloye B. O. and Bolarinwa A.F. (2009) Effect of nicotine administration on weight and histology of some vital visceral organs in female albino rats. Niger J Physiol Sci. 2009 Jun; 24 (1), 7-12.

Jancurova M., Minarovičova L., Dandar A. (2009) Quinoa - a review. Czech J. Food Sci., 27, 71-79.

Jancurová, M., Minarovičová, L. \& Dandár, A. (2009) Quinoa - a Review. Czech J. Food Sci., 27 (2), 7179.

Kakkar, P.; Das, B. and Viswanathan, P.N. (1984) A modified spectrophotometric assay of superoxide dismutase. Indian J. Biochem. Biophys., 21, 130132.

Kikuchi-Hayahawa, M.; Onodera, N.; Matsubara, S.; 
Yasudo, E. Chonan, O.; Takahashi, R. and Ishikawa, F. (1998) Effect of soy milk and bifidobacterium fermented soymilk on lipid metabolism in aged avariectomized rats. Bioscience Biotechnology and Bio chemistry, 62 (9), 1688-1692 .

Kuljanabhagavad, T., Thongphasuk, P., Chamulitrat, W. \& Wink, M. (2008) Triterpene saponins from Chenopodium quinoa Willd. Phytochemistry, 69, 1919-1926.

Lee, I. (2015) Betaine is a positive regulator of mitochondrial respiration. Biochem. Biophys Res. Commun. 456, 621-625.

Lindsey, W.L. and M.A. Norwell, (1969) A new DPTATEA soil test for zinc and iron. Agronomy Abstracts, 61, 84 .

Lopes-Virella, M.F.; Stone, S.; Ellis, S. and Collwell, J. A. (1977) Cholesterol determination in highdensity lipoprotein separated by three different methods. Clin. Chem., 23 (5), 882.

Mandal, K.; Dasgupta, S. and Chattopadhyay, B.D. (2004) Nicotine induced alterations on reproductive organs of female rats under protein deficientcondition. Indian J. Exp.Biol. 42, 330-33

Mansour E.H. and T.A. El-Adawy, (1994): Nutritional potential and eunctional properties of heat treated and germinated fenugreek seeds. Lebensmittel Wissenschaft Technologie, 27, 568-572.

Miranda, M., Vega-Gálvez, A.,Martinez, E.A., Lópeza, J., Marín,R., Aranda, M. \& Fuentes, F. (2013): Influence of contrasting environment on seed composition of two quinoa genotypes: nutri tional and functional properties. Chilean Journal of Agricultural Research, 73 (2), 108-116.

Muthukumaran, S.; Sdheer, AR.; Menon, VP. and Nalini, N. (2008): Protective effect of quercetin on nicotine induced prooxidant and antioxidant imbalance and DNA. 13 (5), 217-24.

Ogawa, H., Watanabe, K., Mitsunaga, T. \& Meguro, T. (2001) Effect of quinoa on blood pressure and lipid metabolism in dietinduced hyperlipidemic spontaneously hypertensive rats (SHR). J. Jpn Soc Nutr Food Sci, 54, 221-227.

Okhawa, H.; Ohishi, N. and Yagi, K. (1979) Assay for lipid peroxidation in animal tissues by thiobarbituric acid reaction. Annals of Biochemistry, 95, 351-358.

Ozukutat, BH.; Ozkan, KU.; Ibrahim, CF.; Guldur, E.; Kilinc, MS. And Inan, F. (2005) Effects of maternal nicotine exposure during on breast fed rat pups. Biol. Neonats. 88 (2), 113-117.

Pasko, P., Barton, H., Zagrodzki, P., Izewska, A., Krosniak, M., Gawlik, M., Gawlik, M. \& Gorinstein, S. (2010a) Effect of Diet Supplemented with Quinoa Seeds on Oxidative Status in Plasma and Selected Tissues of High FructoseFed Rats. Plant Foods Hum Nutr. 65, 146-151.

Pasko, P., Zagrodzki, P., Barton, H., Chlopicka, J. \& Gorinstein, S. (2010b) Effect of Quinoa Seeds (Chenopodium quinoa) in Diet on some Biochemical Parameters and Essential Elements in Blood of High Fructose-Fed Rats. Plant Foods Hum Nutr., 65, 333-338.

Patton , C. J. and Crouch , S.R. (1977) "Enzymatic colorimetric method for determination of urea in serum". Anal. Chem. 49, 464- 469

Reitman, S. and Frankel, S. (1957): A colorimetric method for the determination of serum glutamic oxaloacetic and glutamic pyruvic transaminases. Am. J. Clin. Path. 28, 56.

Repo-Carrasco-Valencia,R.A.M. \& Serna, L.A. (2011): Quinoa (Chenopodium quinoa, Willd.) as a source of dietary fiber and other functional components. Ciênc Tecnol Aliment, 31(1), 225-230.

Repo-Carrasco-Valencia R, Hellstrom JK, Pihlava JM, Mattila PH (2010) Flavonoids and other phenolic compounds in Andean indigenous grains: Quinoa (Chenopodium quinoa), kañiwa (chenopodium pallidicaule) and kiwicha (Amaranthus caudatus). Food Chemistry, 120, 128-133.

Repo-Carrasco R, Espinoza C and Jacobsen SE, (2003) Nutritional value and use of the Andean crops quinoa (Chenopodium quinoa) andka niwa (Chenopodium pallidicaule). Food Rev Int. 19, 179-189

Rodriguez-Amaya, D.B. (1997) Carotenoids and Food preparation: The Retention of Provitamin A Carotenoids in Prepared, Processed and Stored Foods. John Snow, Inc./OMNI Project, Arlington, VA

Ross A.B., Bruce S.J., Blondel-Lubrano A., OgueyAraymon S., Beaumont M. (2011) A whole-grain cereal-rich diet increases plasma betaine, and tends to decrease total and LDL-cholesterol compared with refined-grain diet in healthy subjects. British Journal of Nutrition, 105, 1-12.

Ruales, J. \& Nair, B. (1993b) Saponins, phytic acid, tannins and protease inhibitors in quinoa (Chenopodium quinoa, Willd.) seeds. Food Chem. 48, 137-143.

Egypt. J. Food. 47, No. 2 (2019) 
Sendecor, G.W. and Cochran, W.C. (1967) Statistical Methods, 6th ed. The Lowa State Univ. Press, Ames, U.S.A.

Shabala, L., Mackay, A., Tian, Y., Jacobsen, S.E., Zhou, D. et al. (2012) Oxidative stress protection and stomatal patterning as components of salinity tolerance mechanism in quinoa (Chenopodium quinoa). Physiologia Plantarum, 146, 26-38.

Simnadis, T. George., Tapsell, L. C. and Beck, E. J. (2015) Physiological effects associated with Quinoa consumption and implications for research involving humans: a review. Plant Foods for Human Nutrition, 70, 238-249.

Sreeparna, Neogy; Subhasis, Das; Mahapatra, S. K.; Nirjal, Mandal and Somenath, Roy (2008) Amelioratory effect of Andrographis paniculata Nees on liver, kidney, heart, lung and spleen during nicotine induced oxidative stress. Food and Chemical Toxicology, 2008. 48 (11), 546-553.

Takao T, Watanabe N, Yuhara K, Itoh S, Suda S, Tsuruoka Y, Nakatsugawa K, Konishi Y. (2005) Hypocholesterolemic effect of protein isolated from quinoa (Chenopodium quinoa Willd.) seeds. Food Sci. Technol. Res. 11 (2),161-7.

Tang H., Watanabe K., Mitsunaga T. (2002) Characterization of storage starches from quinoa, barley and adzuki seeds. Carbohydrate Polymers, 49, 13-22.

Tang Y, Li X, Chen PX, Zhang B, Hernandez M, et al. (2015b) Characterisation of fatty acid, carotenoid, tocopherol/tocotrienol compositions and antioxidant activities in seeds of three Chenopodium quinoa Willd. genotypes. Food Chemistry, 174, 502-508.

Trinder, P. and Ann, S. (1969) Enzymatic colorimetric test with lipid clearing factor to determine triglycerides. Clin. Biochem. , 6, 24-27. USDA, (2013) U.S. Department of Agriculture. Agricultural Research Service. 2013a. National Nutrient Database for Standard Reference, Release 26. Nutrient Data Laboratory Home. Page, http:// www.ars.usda.gov/ ba/bhnrc/nd (accessed on October 2013).

Vega-Gálvez A., Miranda M., Vergara J., Uribe E., Puente, L. et al. (2010) Nutrition facts and functional potential of quinoa (Chenopodium quinoa Willd.), an ancient Andean grain: a review. J. Sci. Food Agric. 90, 2541-2547.

Velarde-Salcedo, A. J., de Mejía, A. P. B. and devla Rosa, E. G. (2012) In Vitro Evaluation of the Antidiabetic and Antiadipogenic Potential of Amaranth Protein Hydrolysates. Hispanic Foods: Chemistry and Bioactive Compounds, Chapter 12, pp. 189-198.

Whitehead, A., Beck, E.J., Tosh, S., Wolever, TMS (2014) Cholesterol-lowering effects of oat $\beta$-glucan: a meta-analysis of randomized controlled trials. Am. J. Clin. Nutr. 100 (6),1413-1421

Willis D, Popovech M, Gany F, Hoffman C, Blum J, Zelikoff J.(2014); Toxicity of gutkha, smokeless tobacco product gone global: is there more to the toxicity than nicotine. Int. J. Environ Res Public Health. 2014;11:919-933.

Wu, YP. ; Kita, K. and Suzuki, N. (2002): Involvement of human heat shock protein in nicotine induced apoptosis. Int. J. Cancer, 90 (100), 37-42

Yildiz, D. (2004) Nicotine, its metabolism and an overview of its biological effects. Toxicon. 43, 619-632. 